\title{
Futuring Together: Inside and Outside of Marriage in Namibia
}

\author{
Julia Pauli
}

What is the future of marriage in Namibia, possibly southern Africa? A woman from rural Fransfontein, northwest Namibia, told me many years ago that marriage is always about "futuring together". If you don't future together, she said, then the relationship will not last. At the time she was in her mid-twenties, unmarried and the mother of a three-year-old daughter. In detail, she described how the father of her child had disappointed her, not seeing their future together. Although he made some money in construction work, he did not put any of it aside for their marriage. He is a selfish person, she said, not thinking ahead. To get married, it takes a lot of effort, and marriage is expensive now, she sighed. Her frustration was not, however, pervasive. She was living with her mother, unmarried like herself, and with a permanent income as a government employee. Mother and daughter shared what they had. By local criteria, their standard of living was high. When I met the mother one Sunday after church, we got into a conversation. She explained that several years ago she had decided that she had had enough of marriage and men. Why compromise, she asked, when you don't have to?

In a nutshell, these two episodes pinpoint why marriage is desirable but not necessary in contemporary Namibia. Marriage in Namibia has changed from an inclusive into an exclusive institution. Similar dynamics have been described in Botswana and South Africa (Mhongo and Budlender 2013; Mohlabane et al. 2019; Pauli and van Dijk 2016; Posel and Rudwick 2014; Reece 2019; van Dijk 2017). In inclusive times, in Namibia approximately until the 1970s, most Namibians were either married or on their way towards marriage. In a process that sometimes took years, marriage was negotiated and eventually finalized between kin groups. Exclusive marriage emerged when wedding costs started to soar about forty years ago. In a long-term process, economic stratification, fostered by the apartheid state, turned into deep class differences. Increasingly, only wealthy Namibians could afford the ever more costly weddings. Namibia changed from being a country with a high marriage rate to one with a low marriage rate. As a result, contemporary intimate relations can be characterized as bipartite. On the one hand, a small group of middle- and

(C) JULIA PAUli, 2022 | DOI:10.1163/9789004471641_028 
upper-class Namibians appropriated marriage and turned it into a class project. This appropriation has reconfigured the meaning and practices of marriage along neoliberal lines. On the other hand, intimacy, conjugality and parenthood continue to be of great importance for the vast majority of the unmarried population. There is a lot of 'futuring together', albeit outside marriage.

If the future of marriage in Namibia continues along these lines, what does this mean for kinship, care networks and general social organization? I suggest that the bipartite division of intimate relations into married versus unmarried Namibians leads to different, but connected social universes for the respective groups. My informed guesswork is based on long-term fieldwork undertaken in rural and urban Namibia since 2003 (Pauli 2019, 2020). Between 2003 and 2006 I focused on rural livelihoods in Fransfontein, northwest Namibia, where most people consider themselves to be Damara and speak Khoekhoegowab (Schnegg 2019: 834). However, given the high level of intermingling between rural and urban populations (Greiner 2011; Pauli 2020), I undertook a followup study in Windhoek, in urban Namibia, in 2015/16, in which I deliberately focused on the so-called rising middle classes and their marriages. My urban sample consisted of interlocutors I already knew from Fransfontein who had meanwhile moved to Windhoek. To broaden my view, I decided to include married middle-class couples from other ethnic and language groups, mainly Oshiwambo speakers (for more details see Pauli 2020).

Married Namibians under forty most likely live in an urban middle-class environment. Kaylee and Adam, who married in October 2015, communicated with one another in Khoekhoegowab, but sometimes switched to English, and addressed each other by their Western names (for which I am using pseudonyms); they only used their Damara names when visiting rural kin. Kaylee was $3^{1}$ and Adam $3^{2}$ when they celebrated their wedding at an expensive safari lodge outside Windhoek. They had fallen in love at a soccer game in the national stadium in 2009 and, a few years into their relationship, Kaylee moved in with Adam. When I met them in 2015, they were saving up to buy a house in Rocky Crest, one of the new middle-class neighbourhoods of Windhoek. Kaylee explained that the big house was an investment in their future as a family and that she had stopped using contraceptives a few months earlier. Adam and Kaylee, who have international university degrees in accounting and taxation, worked for insurance companies and were enjoying incomes way above the average. They dined out several times a week, went on nice holidays, and lived comfortable lives.

Kaylee emphasized the preciousness of her love for Adam and, like many other married urbanites I interviewed in Windhoek in 2015 and 2016, she saw her marriage as something that needed constant effort to grow. At length, 
Kaylee listed the many things she did for her own growth and for the growth of their relationship. Three times a week she went to Virgin Active, a fitness club, to stay slim and fit. Because Adam loved outdoor sports, she organized trips to the countryside. They had special date nights and went shopping for each other. Constant reflections on how to improve the quality of their relationship complemented this "consumption of the romantic utopia" (Illouz 1997; see also Mupotsa 2014, 2015). Kaylee stressed how much work they put into their communication skills. Despite their heavy workloads, the couple tried to spend as much time as possible together, investing in their relationship. Adam also worked on his growth. "I love him so much," Kaylee said, "because he decided, besides his background, he could still excel and try to grow himself."

Working on love as aspiration and labour, Danai Mupotsa (2014) has shown how South African weddings are performances of the neoliberal idea of "the good life" (Mupotsa 2014: 256). Kaylee and Adam's futuring together builds on comparable neoliberal constructions of the self (Freeman 2014; Gershon 2011). Emily Martin has pointed out that the quintessential foundation of neoliberal selfhood is the perception that people are "a collection of assets that must be continually invested in, nurtured, managed, and developed" (Martin 2000: 582). For the married, middle-class Namibians with whom I spoke in 2015 and 2016, only multiple investments in one's self, one's relationship and one's partner led to fulfilling marriages; and these investments were highly time consuming. Many couples complained that their kin did not understand these social priorities. The couples wanted to invest time and resources in their coupledom and not their kin. Unclear distributions of time and resources caused conflicts among couples and with their kin. While Kaylee came from a wealthy middleclass family, her father was a university professor and her mother a teacher, Adam's unmarried mother had raised five children from four different men on her own. Adam was the only married child and he supported his mother with visits and a monthly allowance. Kaylee felt ambivalent about this and the couple quarrelled. She feared that his mother's demands would interfere with the quality of their own relationship. "I will tolerate it," Kaylee said, "as long as it does not influence our future and our growth as a married couple."

In contrast to married middle-class Namibians like Kaylee and Adam, unmarried Namibians under forty are most likely to be living with their kin. In both rural and urban Namibia, femifocal households (Pauli 2013), which centre on strong female kin ties like mother-daughter or sister-sister, are widespread. Male relatives are attached to these households but seldom form their core. While living in rural Fransfontein with my husband and fellow anthropologist Michael Schnegg in 2003/4, I discussed motherhood and marriage with 
four young women between the ages of twenty and thirty (Pauli 2019: 199). All were unmarried mothers and I wanted to know if they considered a child more important than a boyfriend, husband or partner; they all insisted that they did. "If a partner should not accept my child from a previous relationship," one woman said, "then I would leave him." Another woman spoke of how her child would stay with her until she grew old and died. Contrary to their married counterparts, unmarried women invested most of their time and resources in their children, their kin and their wider care network, including female neighbours (Pauli 2007a), and not in their heterosexual relationships. For example, 25 year-old Isabel maintained a large reciprocal network of mostly female kin. With her relatives, she exchanged food, clothes, job opportunities, housing and money and shared childcare responsibilities. When I met her in rural Namibia in 2003, she and her three-year-old daughter Holly were living in her mother Dina's household. Dina, a hard-working woman in her sixties, owned and headed the household of 12 people, which basically comprised her mother Verena and five grandchildren; however, Isabel, two of her older brothers, a female cousin and a brother's friend were also temporarily staying there. The only married, now widowed person in the household was 84-year-old Verena (Pauli 2019). Isabel and Dina had never married, and both women expressed scepticism towards men. Occasionally, the fathers of their children helped them with something, they told me, sometimes money, sometimes food, maybe a goat, but these gifts were not to be relied on. "My mother and my small mothers (mother's younger sisters), they make me live," Isabel said. Vice versa, Isabel did everything to support her mother and her female kin.

Catherine Allerton (2007) has argued that it is very Euro-American to view unmarried people, especially women, as 'alone', 'lonely' and 'needy'. Building on Erving Goffman's distinction between 'single' and 'withs' (Goffman 1971), Allerton observes in relation to her Indonesian fieldwork, "Although unmarried women may have a 'single status' with regard to marriage, in terms of wider social life they are most definitely 'withs', whether connected with another unmarried sister, their parents, or their brother and his children" (Allerton 2007: 21). Like Allerton's Indonesian interlocutors, most people in Namibia thought it terrible to be 'single' in Goffman's sense. However, contrary to Euro-American and middle-class Namibian perceptions, marriage was not necessarily considered the only way of avoiding being 'single' and lonely. Sharing a house and food, fostering a child and living and 'futuring' together were some of the many ways in which unmarried people in rural and urban Namibia became 'withs'. Unmarried Fransfonteiners do not need marriage to be socially accepted and have socially satisfying lives and futures.

To conclude, I want to relate my observations to findings from other regions. Jane Guyer has described two different 'logics' of marriage and reproduction 
for Nigeria (Guyer 1994). The 'lineal' logic is based on marriage. The tie created through marriage is long-term and stable, but it also limits a woman's agency and flexibility. The second logic is classified as 'lateral'. Many Yoruba mothers in Western Nigeria cultivate co-parental ties with more than one father of their children, resulting in an arrangement that Guyer (1994: 231) terms 'polyandrous motherhood'. Polyandrous motherhood leads to complex social networks based on co-parenthood. Women gain flexibility and can claim support from multiple men in times of need. Guyer's lateral logic describes the social universe of many unmarried Namibians. Co-parental ties to several men are very common for unmarried Namibian women (Pauli 2007b). Furthermore, support from multiple fathers is embedded in dense female kin and care networks. This social organization has developed over decades in southern Africa and is very likely to continue in the future (see for example Boehm 2006; Hellman 1974; Preston-Whyte 1978; Van der Vliet 1984).

Guyer's 'lineal' logic is also helpful in understanding the social universe of contemporary married middle-class Namibians. However, Guyer's 'lineal' logic, highlighting the genealogical connections between generations, has been reconfigured into a 'neoliberal' logic of marriage in Namibia, focusing on the heterosexual couple. Recent comparative work suggests that these trends will continue and deepen in the future. Juliette Crespin-Boucaud has shown that in many African countries inter-ethnic marriages are on the rise (Crespin-Boucaud 2020). She speculates that changes in gender relations and an increased agency of educated, urban women have opened the marriage market beyond ethnicity. Similarly, Rachel Spronk's work on young middle-class professionals in Nairobi demonstrates the relevance of social class and the irrelevance of ethnicity for partner choice (Spronk 2012). All of this indicates that the institution of marriage is moving from kin and regional alliance towards consolidation and performance of social class, a dynamic attentive ethnographers have forecasted decades ago (Gulbrandsen 1986; Solway 1990). Although many kin groups are still multi-class entities with ties cutting across status and class, married and unmarried Namibians are socially moving apart from each other, futuring less together and more on their own.

\section{Acknowledgements}

I am very thankful to my interlocutors in Fransfontein and Windhoek for their ongoing support of my research. For their insights and comments on my thinking about marriage and intimacy in southern Africa, I thank Michael Schnegg, Rijk van Dijk, Jaqueline Solway, Koreen Reece, Janet Carsten, Susan McKinnon, Ndeyapo Nickanor, Adam Kuper, Erdmute Alber, Cati Coe, Doreen Setume, 
Clemens Greiner, Michael Bollig, Pamela Feldman-Savelsberg, Lena Kroeker and Stephanie Rudwick.

\section{References}

Allerton, C. 2007. "What does it mean to be alone?" In Questions of anthropology, edited by R. Astuti, J. Parry and C. Stafford, 1-28. Oxford: Berg.

Boehm, C. 2006. "Industrial labour, marital strategy and changing livelihood trajectories among young women in Lesotho." In Navigating youth, generating adulthood: Social becoming in an African context, edited by C. Christiansen, M. Utas and H. E. Vigh, 153-182. Uppsala Nordic Africa Institute.

Crespin-Boucaud, J. 2020. "Interethnic and interfaith marriages in sub-Saharan Africa." World Development, 125: 1-19.

Freeman, C. 2014. Entrepreneurial selves. Neoliberal respectability and the making of a Caribbean middle class. Durham, NC: Duke University Press.

Gershon, I. 2011. "Un-friend my heart: Facebook, promiscuity, and heartbreak in a neoliberal age." Anthropological Quarterly, 84, 4: 865-894.

Goffman, E. 1971. Relations in public: Microstudies of the public order. London: Allen Lane.

Greiner, C. 2011. "Migration, translocal networks and socio-economic stratification in Namibia." Africa, 81, 4: 6o6-627.

Gulbrandsen, Ø. 1986. "To marry — or not to marry: Marital strategies and sexual relations in a Tswana Society." Ethnos, 51, 1/2: 7-28. DOI: 10.1080/00141844.1986.9981311.

Guyer, J. I. 1994. "Lineal identities and lateral networks: The logic of polyandrous motherhood." In nuptiality in sub-Saharan Africa, edited by C. H. Bledsoe and G. Pison, 231-252. Oxford: Clarendon.

Hellman, E. 1974. "African townswomen in the process of change." South Africa International, 5, 1: 14-22.

Illouz, E. 1997. Consuming the romantic utopia: Love and the cultural contradictions of capitalism. Berkeley: University of California Press.

Martin, E. 200o. "Mind-body problems." American Ethnologist, 27, 3: 569-59o. DOI: 10.1525/ae.2000.27·3.569.

Mhongo, C. and D. Budlender. 2013. "Declining rates of marriage in South Africa: What do the numbers and analysts say?" In Marriage, land and custom. Essays on law and social change in South Africa, edited by A. Claassens and D. Smythe, 181-196. Claremont: Juta.

Mohlabane, N., N. Gumede and Z. Mokomane. 2019. “Attitudes towards marriage." In Family matters: Family cohesion, values and wellbeing, edited by Z. Mokomane, B. Roberts, J. Struwig and S. Gordon, 156-181. Cape Town: HSRC Press. 
Mupotsa, D. 2014. "White weddings." PhD dissertation, University of Witwatersrand. Mupotsa, D. 2015. "The promise of happiness: Desire, attachment and freedom in post/apartheid South Africa." Critical Arts, 29, 2: 183-198. DOI: 10.1080/02560046.2015.1039204.

Pauli, J. 2007a. "Gendered space - female headed households in Fransfontein, northwest Namibia." In Atlas of cultural and environmental change in arid Africa, edited by O. Bubenzer, A. Bolten and F. Darius, 186-189. Cologne: Heinrich-Barth-Institute.

Pauli, J. 2007b. "We all have our own father!' Reproduction, marriage and gender in rural northwest Namibia." In Unravelling taboos: Gender and sexuality in Namibia, edited by S. LaFont, and D. Hubbard, 197-214. Windhoek: Legal Assistance Centre.

Pauli, J. 2013. “'Sharing made us sisters': Sisterhood, migration and household dynamics in Mexico and Namibia." In The anthropology of sibling relations, edited by E. Alber, C. Coe and T. Thelen, 29-5o. New York: Palgrave Macmillan.

Pauli, J. 2019. The decline of marriage in Namibia. Kinship and social class in a rural community. Bielefeld: Transcript.

Pauli, J. 2020. "Class switching. Migrants' multiple identities in rural and urban Namibia." Africa Today, 66, 3/4, 115-135. DOI: 10.2979/africatoday.66.3_4.o6.

Pauli, J. and R. van Dijk. 2016. "Marriage as an end or the end of marriage? Change and continuity in southern African marriages." Anthropology Southern Africa, 39, 4: 257-266. DOI: 10.108 o/23323256.2016.1243451.

Posel, D. and S. Rudwick. 2014. "Marriage and bridewealth (ilbolo) in contemporary Zulu society." African Studies Review, 57, 2: 51-72. DOI: 10.1017/asr.2014.47.

Preston-Whyte, E. 1978. "Families without marriage: A Zulu case study." In Social system and tradition in southern Africa: Essays in honour of Eileen Krige, edited by J. Argyle, and E. Preston-Whyte, 55-85. Cape Town: Oxford University Press.

Reece, K. M. 2019. "We are seeing things': Recognition, risk and reproducing kinship in Botswana's time of AIDs." Africa, 89, 1: 40-60.

Solway, J. S. 199o. "Affines and spouses, friends and lovers: The passing of polygny in Botswana." Journal of Anthropological Research, 46, 1: 41-66.

Spronk, R. 2012. Ambiguous pleasures. Sexuality and middle class self-perceptions in Nairobi. Oxford: Berghahn Books.

Schnegg, M. 2019. "The life of winds: Knowing the Namibian weather from someplace and from noplace." American Anthropologist, 121, 4: 830-844. DOI:10.1111/aman.13274.

Van der Vliet, V. 1984. "Staying single: A strategy against poverty?" In Second Carnegie Inquiry into Poverty and Development in southern Africa. Conference paper no. 116. Cape Town: SALDRU.

van Dijk, R. 2017. "The tent versus lobola: Marriage, monetary intimacies and the new face of responsibility in Botswana." Anthropology Southern Africa, 4O, 1: 29-41. DOI: 10.108 o/23323256.2016.124345o. 